\title{
ANALISIS KESALAHAN NEWMAN PADA PEMECAHAN MASALAH SISWA KELAS VII SMP N 15 YOGYAKARTA
}

\author{
HEPPY OKTAVIANI ${ }^{1}$, KINTOKO $^{2}$, SITI SUPRIHATININGSIH ${ }^{3}$ \\ ${ }^{1}$ Pendidikan Matematika, Universitas PGRI Yogyakarta, Jalan PGRI No. 117 Yogyakarta \\ heppyoktaviani10@gmail.com \\ ${ }^{2}$ Pendidikan Matematika, Universitas PGRI Yogyakarta, Jalan PGRI No. 117 Yogyakarta \\ Corresponding author: kintoko@upy.ac.id \\ ${ }^{3}$ Pendidikan Matematika, STKIP Pamane Talino, Jl. Afandi Rani Ngabang kalimantan Barat \\ s.suprihatiningsih@stkippamanetalino.ac.id
}

First Received: 23-10-2020; Accepted: 20-04-2021

\begin{abstract}
Abstrak
Penelitian ini bertujuan untuk mengetahui jenis kesalahan menurut Newman pada pemecahan masalah matematika siswa. Jenis penelitian yang digunakan dalam penelitian ini yaitu penelitian kualitatif deskriptif. Teknik pengambilan sampel yang digunakan dalam penelitian ini yaitu purposive sampling. Teknik pengumpulan data yang digunakan yaitu tes, wawancara, dan dokumentasi. Tes yang diberikan untuk mengetahui kesalahan siswa berbentuk uraian, sedangkan wawancara dilakukan kepada siswa, dan dokumentasi diperoleh pada saat wawancara dengan siswa. Hasil penelitian menunjukkan bahwa kesalahan pada pemecahan masalah matematika siswa kelompok tinggi yaitu kesalahan mentranformasikan. Sedangkan siswa kelompok sedang yaitu kesalahan mentranformasikan dan kesalahan dalam keterampilan proses. Untuk siswa kelompok rendah yaitu kesalahan dalam memahami soal, kesalahan mentranformasikan, kesalahan dalam keterampilan proses dan kesalahan dalam menuliskan jawaban akhir. Penyebab kesalahan dalam pemecahan masalah berbentuk cerita adalah tidak memahami soal dengan seksama, tidak menuliskan rumus, tidak mengetahui cara mengoperasikan soal dan tidak mengecek kembali jawaban yang sudah dikerjakan.
\end{abstract}

Kata kunci: Analisis Kesalahan; Newman; Pemecahan Masalah; Matematika

\section{NEWMAN ERROR ANALYSIS ON PROBLEM SOLVING OF SEVENTH GRADE OF SMP N 15 YOGYAKARTA}

\begin{abstract}
This study aims to determine the types of errors according to Newman in students' mathematical problem-solving. This used descriptive qualitative research. The sampling technique used in this study was purposive sampling. The data techniques used were tests, interviews, and documentation. Tests were given to find out the students' errors in answering essay questions, while interview was carried out to the students, and documentation was obtained during interview with students. The results showed that the errors in mathematical problem solving of the high group student was transforming the types of errors. While the moderate group student was transforming and errors in the skill process. For low group student was understanding the questions, transforming the skill process, and determining the final answer. The
\end{abstract}


factor of errors in answering essay questions were that the students did not understand the questions, write the formula, understand how to operate the questions, and check their answers.

Keywords: Error Analysis; Newman; Problem Solving; Mathematics

\section{PENDAHULUAN}

Peran Pendidikan dalam mewujudkan kualitas sumber daya manusia untuk meningkatkan sumber daya manusia melalui pendidikan dan dikembangkan pada pembelajaran matematika (Sudarsana, 2016). Pembelajaran terjadi dengan adanya interaksi antara guru dengan siswa (Jennings et al., 2017) setiap berlangsungnya proses belajar mengajar terdapat rancangan pembelajaran, terlebih dahulu guru merencanakan suatu perencanaan pembelajaran agar proses belajar mengajar berjalan degan baik. Adanya rancangan pembelajaran yang baik dan menarik membuat siwa dapat memahami pelajaran dengan baik dan aktivitas pembelajaran lebih kondusif.

Berbagai masalah terjadi saat mengerjakan matematika, terutama mengerjakan soal pada kehidupan sehari-hari yang biasanya disebut dengan soal cerita (Ariawan \& Pratiwi, 2017). Seperti yang dikemukakan Abdurrahman (2010) yaitu dalam menyelesaikan soal bentuk cerita siswa mengalami kesulitan karena dalam soal tidak ada petunjuk pengerjaan. Mengerjakan soal cerita harus lebih teliti (Mulyadi et al., 2015) karena soal cerita perlu mengasumsikan, mengoperasikan soal sampai dengan penyelesaian. Akan tetapi soal cerita masih dirasa sulit untuk siswa, karena dalam pemecahan masalahnya mempunyai langkah yang sangat banyak untuk mendapatkan penyelesaian yang sesuai, sehingga siswa melakukan kesalahan dalam mengerjakan soal cerita.

Hasil observasi di SMP N 15 Yogyakarta menunjukkan bahwa siswa pada saat menyelesaikan suatu soal cerita banyak mengalami kesulitan. Hal ini dibuktikan dengan tes berupa soal cerita, siswa masih kebingungan untuk memahami maksud dari soal cerita tersebut (Purnama, 2017). Beberapa siswa bisa mengerjakan akan tetapi dalam mengasumsikan maupun menuliskan rumus masih belum benar. Dari beberapa faktor menunjukkan adanya kesalahan dalam menyelesaikan soal cerita.

Analisis merupakan suatu cara yang digunakan untuk melihat, mengamati dan mengetahui secara mendalam pada fenomena yang ada (Wahyuni et al., 2018). Selain itu kesalahan merupakan penyimpangan atau kekeliruan terhadap jawaban dari soal yang benar (Wahbi \& Bey, 2015). Indikator kesalahan menurut Newman Celemen (1980) dalam Oktaviana 
(2018) yaitu (1) kesalahan membaca soal (reading eror), (2) kesalahan dalam memahami soal (chomprehension error), (3) kesalahan mentranformasikan (transformation error), (4) kesalahan dalam keterampilan proses (process skill error), dan (5) kesalahan dalam menuliskan jawaban akhir (ending error). Menurut Mulyadi (2018) soal cerita merupakan soal yang berkaitan dengan masalah sehari-hari yang diselesaikan dengan menggunakan rumus matematika.

Kemampuan pemecahan masalah merupakan kemampuan yang digunakan untuk menentukan unsur diketahui, ditanya dan beberapa unsur yang dibutuhkan dalam menyelesaikan masalah (Fatimah et al., 2020). Indikator pemecahan masalah menurut (Lestari \& Yudhanegara, 2017) yaitu (1) menentukan unsur-unsur yang diketahui, ditanyakan dan unsur lain yang berhubungan, (2) membuat pemodelan matematika, (3) menentukan strategi yang digunakan dalam menyelesaikan masalah, (4) menjabarkan hasil penyelesaian.

\section{METODE PENELITIAN}

Penelitian ini menggunakan motede penelitian kualitatif deskriptif yang bertujuan untuk mendeskripsikan kesalahan dalam pemecahan masalah matematis. Penelitian ini dilakukan pada siswa kelas VII A pada semeter genap tahun ajaran 2019/2020 di SMP N 15 Yogyakarta. Subyek penelitian diambil dari satu kelas yaitu kelas VII A SMP N 15 Yogyakarta. Siswa yang dipilih untuk menjadi subyek penelitian yaitu 3 siswa yang terdiri dari kelompok tinggi, sedang, dan rendah. Tahapan dalam penelitian ini yaitu observasi, penelitian, dan analisis data. Analisis data yang digunakan dalam penelitian ini yaitu reduksi data, penyajian data, dan penarikan kesimpulan. Pemeriksaan keabsahan data pada penelitian ini dilakukan dengan triangulasi yang dilakukan untuk pengecekan atau pembanding data.

\section{HASIL DAN PEMBAHASAN}

Soal yang akan diujikan merupakan materi segiempat dan segitiga kelas VII A, namun sebelum peneliti melakukan uji tes di kelas VII A terlebih dahulu soal diuji coba pada kelas VII $\mathrm{C}$ dengan jumlah 33 siswa. Terdapat 6 soal dengan kategori baik yang akan digunakan untuk penelitian. Hasil uji validitas butir soal dapat dilihat pada Tabel 1. 
Tabel 1. Validitas Butir Soal

\begin{tabular}{cccc}
\hline Butir Soal & r hitung & r tabel & Keterangan \\
\hline 1 & 0,748 & 0,4296 & Valid \\
2 & 0,694 & 0,4296 & Valid \\
3 & 0,469 & 0,4296 & Valid \\
4 & 0,729 & 0,4296 & Valid \\
5 & 0,468 & 0,4296 & Valid \\
6 & 0,678 & 0,4296 & Valid \\
\hline
\end{tabular}

Uji reliabilitas soal untuk mengetahui konsistensi butir-butir instrumen tes. Jumlah pernyataan yang diuji adalah 6 butir pernyataan yang sebelumnya sudah diuji kevalidannya.

Pengujian dilakukan dengan menggunakan rumus Cronbach's Alpha berbantuan software SPSS 16 dengan hasil sebagai berikut.

Tabel 2. Reliabilitas Butir Soal

\begin{tabular}{ccc}
\hline Koefisien Korelasi & Korelasi & Interpretasi Reliabilitas \\
\hline 0,692 & Sedang & Tepat/Baik \\
\hline
\end{tabular}

Uji daya pembeda dilakukan untuk melihat tinggi dan rendahnya suatu daya pembeda butir soal. Setiap butir soal yang sudah divalidasi dan dinyatakan reliabilitas akan duji tinggi rendahnya daya pembeda dengan menggunakan rumus daya pembeda. Hasil perhitungan daya pembeda dapat dilihat pada Tabel 3 berikut.

Tabel 3. Daya Pembeda Butir Soal

\begin{tabular}{ccc}
\hline Butir Soal & Koefisien & Inteprestasi Daya Pembeda \\
\hline 1 & 0,62 & Baik \\
2 & 0,517 & Baik \\
3 & 0,258 & Cukup Baik \\
4 & 0,556 & Baik \\
5 & 0,249 & Cukup Baik \\
6 & 0,407 & Baik \\
\hline
\end{tabular}

Uji kesukaran soal digunakan untuk mengetahui mudah atau sulit suatu soal, biasanya tingkat kesukaran suatu soal dinyatakan dengan indeks kesukaran. Soal yang divalidasi dan dinyatakan reliabel kemudian diuji tingkat kesukaran dengan rumus indeks kesukaran. Hasil uji tingkat kesukaran dapat dilihat pada Tabel 4 berikut.

Tabel 4. Indeks Kesukaran Butir Soal

\begin{tabular}{ccc}
\hline Butir Soal & Koefisien & Inteprestasi Daya Pembeda \\
\hline 1 & 0,758 & Mudah \\
2 & 0,744 & Mudah \\
3 & 0,825 & Mudah \\
4 & 0,710 & Mudah \\
5 & 0,411 & Sedang \\
6 & 0,710 & Mudah \\
\hline
\end{tabular}


Hasil pengelompokkan diperoleh siswa dengan kategori tinggi sebanyak 2, siswa dengan kategori sedang 26, dan siswa dengan kategori rendah sebanyak 5. Subjek yang dipilih sebanyak 3 siswa yaitu 1 untuk kemampuan tinggi, 1 siswa untuk kemampuan sedang, dan 1 siswa untuk kemampuan rendah.

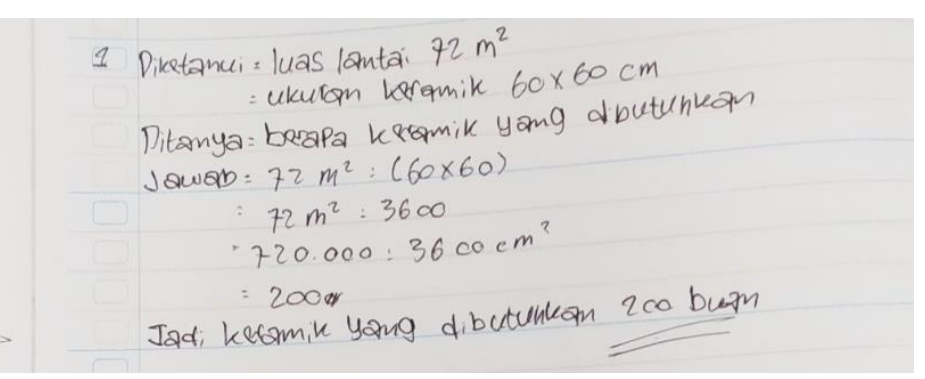

Gambar 1. Subjek S1

Adapun hasil wawancara:

$\mathrm{H}$ : Apakah soalnya bisa dipahami?

$\mathrm{S} 1$ : Bisa dipahami mbak.

$\mathrm{H}$ : Apa saja yang dijelaskan di soal?

S1 : Luas lantai dan ukuran kramik.

$\mathrm{H}$ : Apakah sudah ada gambaran rumus yang akan digunakan?

S1 : Itu mbak yang saya kurang paham dengan rumus.

$\mathrm{H}$ : Apakah ada kesulitan pada pengoperasian soal.

S1 : Tidak mbak.

Dari pekerjaannya siswa tersebut tidak melakukan langkah kedua tetapi dia mampu menuliskan apa yang diketahui dan ditanyakan serta mampu mengoperasikan dengan langkahlangkah yang benar. Berdasarkan hasil wawancara dan melihat soal yang dikerjakan pada soal nomor 1 bahwa S1 mengalami kesalahan Newman pada langkah mentranformasikan atau menuliskan rumus.

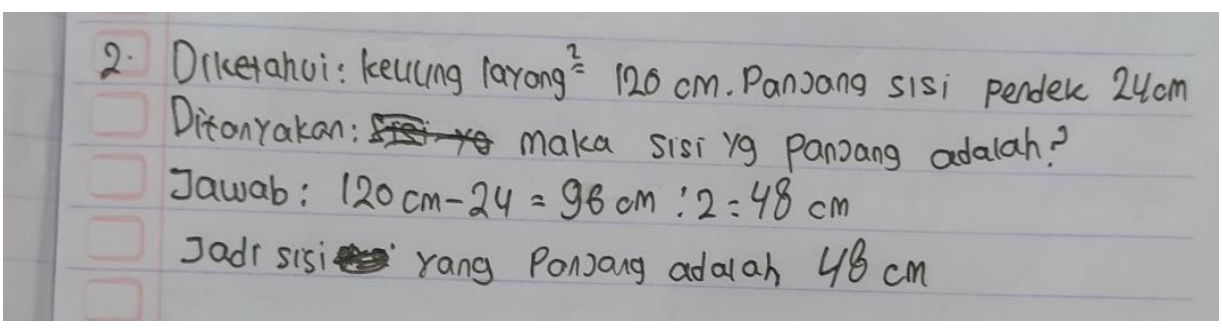

Gambar 2. Subjek S2

Adapun hasil wawancara:

$\mathrm{H}$ : Bagaimana dengan soal no 2, Apakah bisa dipahami?

S2 : Ya, mbak paham dengan soal no 2 
$\mathrm{H}$ : Apa saja yang diketahui pada soal?

S2 : Keliling layang-layang dan panjang sisi pendek layang-layang.

$\mathrm{H}$ : Apakah sudah ada gambaran rumus yang akan digunakan?

S2 : Itu mbak yang saya kurang paham dengan rumus.

$\mathrm{H}$ : Apakah ada kesulitan pada pengoperasian soal.

S2 : Itu juga mbak sya ketika mengerjakan pengoperasian bingung pada perhitungan mencari sisi pendek.

Dari pekerjaan siswa tersebut tidak melakukan langkah Newmann yang kedua dan ketiga tetapi dia mampu menuliskan apa yang diketahui dan ditanyakan serta menuliskan kesimpulan jawaban. Berdasarkan hasil wawancara dan melihat soal yang dikerjakan pada soal nomor 2 bahwa S2 terdapat kesalahan Newman tahap mentransformasikan atau menuliskan rumus dan dalam keterampilan proses.

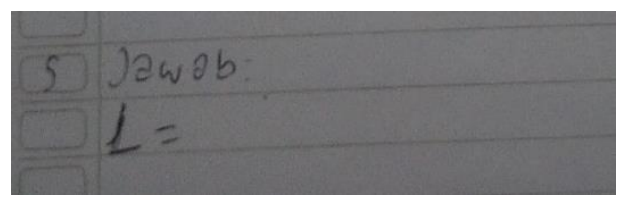

Gambar 3. Subjek S3

Hasil wawancara dengan S3 pada soal nomor 5.

$\mathrm{H}:$ Bagaimana dengan soal no 5?

S3 : Masih bingung mbak.

$\mathrm{H}$ : Apa yang diketahui dalam soal tersebut?

S3 : Karena saya tidak paham jadi saya tidak tahu mbak apa yang diketahui.

$\mathrm{H}$ : Pada soal tersebut rumus apa yang digunakan?

S3 : Saya kurang paham mbak untuk rumusnya.

$\mathrm{H}$ : Bagian mana yang menurut kamu sulit?

S3 : Tidak mengerti mau diapakan soalnya mbak, saya belum mengerti maksudnya.

Berdasarkan hasil wawancara dan melihat soal yang dikerjakan pada soal nomor 5 bahwa S3 mengalami kesalahan pada semua kesalahan Newman yaitu kesalahan pada memahami soal, kesalahan mentranformasikan, kesalahan dalam keterampilan proses, kesalahan dalam menuliskan jawaban akhir.

Dari 3 siswa sebagai subjek penelitian siswa kelompok tinggi terdapat kesalahan dalam menuliskan rumus dengan persentase kesalahan 50\%. Siswa kelompok sedang terdapat kesalahan dalam menuliskan rumus dengan persentase 50\%, dan menggunakan cara dalam menyelesaikan persoalan dengan persentase 25\%. Pada kelompok rendah terdapat pada semua indikator kemampuan pemecahan masalah yaitu kesalahan menjabarkan semua unsur yang ada dalam soal dan dinyatakan dan kesesuaian unsur yang akan digunakan untuk menyelesaikan 
soal dengan persentase $44 \%$, perumusan soal atau penyusunan pemodelan soal matematika dengan persentase $92 \%$, membuat cara dalam menyelesaikan soal dengan persentase $25 \%$, dan menjelaskan atau mingintreprestasikan hasil penyelesaian dengan persentase $92 \%$.

\section{SIMPULAN}

Hasil penelitian menunjukkan bahwa jenis kesalahan dalam pemecahan masalah matematis siswa kelompok tinggi yaitu kesalahan mentranformasikan. Jenis kesalahan siswa kelompok sedang yaitu kesalahan mentranformasikan, serta kesalahan dalam melakukan proses penyelesaian masalah. Jenis kesalahan siswa kelompok rendah yaitu kesalahan dalam menafsirkan soal, kesalahan mentranformasikan, kesalahan dalam membuat langkah-langkah penyelesaian, dan kesalahan menuliskan jawaban akhir. Penyebab kesalahannya adalah tidak memahami soal dengan seksama, tidak menuliskan rumus, tidak mengetahui cara mengoperasikan soal dan tidak mengecek ulang jawaban. Berdasarkan analisis data kesalahan siswa yang mengalami banyak kesalahan adalah siswa berkemampuan rendah, karena pada siswa berkemampuan rendah terdapat kesalahan pada semua indikator kesalahan yaitu dengan persentase kesalahan rata-rata $44 \%$, merumuskan suatu masalah matematis yang terdapat pada soal atau menyusun suatu pemodelan soal matematika dengan persentase $92 \%$, menggunakan teknik dalam menyelesaiakan persoalan matematika dengan persentase $25 \%$, dan menginterpretasikan hasil penyelesaian dengan persentase $92 \%$.

\section{DAFTAR PUSTAKA}

Abdurrahman, M. (2010). Pendidikan Bagi Anak Berkesulitan Belajar. Jakarta. Rineka Cipta.

Ariawan, V. A. N., \& Pratiwi, I. M. (2017). Eksplorasi Kemampuan Siswa Kelas Iv Sekolah Dasar Dalam Penyelesaian Soal Cerita Matematika. JPI (Jurnal Pendidikan Indonesia), 6(1), 82-95. https://doi.org/10.23887/jpi-undiksha.v6i1.9184

Fatimah, Siregar, E. Y., \& Ahmad, M. (2020). Realistik Terhadap Kemampuan Pemecahan Masalah Matematis Siswa Smk Negeri 1 Batang. 3(1), 37-45.

Jennings, P. A., Brown, J. L., Frank, J. L., Doyle, S., Oh, Y., Davis, R., Rasheed, D., Deweese, A., Demauro, A. A., Cham, H., Greenberg, M. T., Impacts, F., Jennings, P. A., Brown, J. L., Frank, J. L., Doyle, S., Davis, R., \& Greenberg, M. T. (2017). Journal of Educational Psychology Impacts of the CARE for Teachers Program on Teachers 'Social and Emotional Competence and Classroom Interactions.

Lestari, E. K., \& Yudhanegara, R. M. (2017). Penelitian Pendidikan Matematika. Bandung. PT Rafika Aditama. 
Mulyadi, S. (2018). Analisis Keslahan Siswa Kelas Dalam Menyelesaikan Soal Cerita Ditinjau Dari Perbedaan Gender. APOTEMA: Jurnal Program Studi Pendidikan Matematika, 4(1), 80-8

Mulyadi, Riyadi, \& Subanti, S. (2015). Analisis Kesalahan Dalam Menyelesaikan Soal Cerita Pada Materi Luas Permukaan Bangun Ruang Berdasarkan Newman'S Error Analysis (Nea) Ditinjau Dari Kemampuan Spasial. Jurnal Elektronik Pembelajaran Matematika, 3(4), 370-382. http://jurnal.fkip.uns.ac.id

Oktaviana, D. (2018). Analisis Tipe Kesalahan Berdasarkan Teori Newman Dalam Menyelesaikan Soal Cerita Pada Mata Kuliah Matematika Diskrit. Edu Sains: Jurnal Pendidikan Sains \& Matematika, 5(2), 22. https://doi.org/10.23971/eds.v5i2.719

Purnama, M. B. (2017). Analisis Kesalahan Siswa dalam Menyelesaikan Soal Cerita Materi Operasi Hitung Campuran (Perkalian dan Pembagian) di Kelas II SDN Ngaban. 1-12. http://eprints.umsida.ac.id/id/eprint/525

Sudarsana, I. K. (2016). Peningkatan Mutu Pendidikan Luar Sekolah Dalam Upayapembangunan Sumber Daya Manusia. Jurnal Penjaminan Mutu, 1(1), 1. https://doi.org/10.25078/jpm.v1i1.34

Wahbi, A. \& Bey, A. (2015). Analisis Kesalahan Siswa Dalam Menyelesaikan Soal Faktorisasi Suku Aljabar Ditinjau Dari Objek Matematika Pada Siswa Kelas VIII SMP Negeri 15 Kendari. Jurnal Penelitian Pendidikan Matematika, 3(1), 19-30.

Wahyuni, J., Paranthy, Y. W., \& Wanto, A. (2018). Analisis Jaringan Saraf Dalam Estimasi Tingkat Pengangguran Terbuka Penduduk Sumatera Utara. Jurnal Infomedia, 3(1). https://doi.org/10.30811/jim.v3i1.624. 